\title{
Construction and Practice of the System for Teaching Information Staff in Undergraduate Colleges and Universities
}

\author{
Dongyun $\operatorname{Sun}^{1}$ \\ ${ }^{1}$ Changchun University of Science and Technology, Changchun, China \\ Correspondence: Dongyun Sun, Changchun University of Science and Technology, Changchun 130022, Jilin, China. \\ E-mail:wj1329@yeah.net
}

Received: August 13, 2014

Accepted: August 25, 2014

Online Published: October 22, 2014

doi:10.5430/jms.v5n4p94

URL: http://dx.doi.org/10.5430/jms.v5n4p94

\begin{abstract}
Improvement of teaching quality benefits from continuous discovery of problems and resolution of problems. Furthermore, construction of the system of information staff in undergraduate colleges and universities is able to better excavate problems that actually exist in activities of teaching. This enables education practitioners to continue to consummate and improve their method of teaching and achieve the objective of enhancing quality of teaching. The system of information staff is an important component to do a good job of control over teaching quality. This paper briefly expounds the significance, management, several problems existing and several thoughts in the system of information staff in combination with practice of undergraduate colleges and universities.
\end{abstract}

Keywords: teaching quality, teaching information staff, teaching management

With development of the economy and process of the society, the government and enterprises are in sore need of high-end talents, whereas deficiency of talents is the key to restraining development of every walk of life. Undergraduate colleges and universities burden the heavy responsibility of cultivating talents. However, as a large majority of undergraduate colleges and universities has only a relatively short history of school running, and they have no qualification to compare with European and American developed countries whether in terms of inside deposits or in terms of experience in school running, this requires the colleges and universities to try every means to improve the quality of talent cultivation and diminish the gap with talent cultivation in western developed countries. They are required to pay attention to all kinds of problems existing in the process of teaching at all time and resolve these problems in due course so as to achieve ultimately the purpose of enhancing teaching quality. However, it is far from enough to merely rely on the teaching management personnel who only account for a small proportion of the total number of teachers. It is required to make full use of the object for whom the service is provided - students. Therefore, after exploration and implementation for some time, undergraduate colleges and universities respectively construct their own student teaching information staff system.

The system of student information staff is an important aspect in the system of teaching quality control and evaluation in undergraduate colleges and universities and enables undergraduate colleges and universities to improve their teaching management quality. It fully embodies the dominant position of students. As an organization that provides teaching information, it mainly undertakes collection and feedback of teaching first-line information, including teaching management, classroom teaching, condition of style of learning, condition of teaching and daily life, etc. This paper makes explorations in the system of teaching information staff in combination with practice.

\section{Functions of the System for Teaching Information Staff}

\subsection{To Promote Improvement of the Level of Teaching Management}

With expansion of the enrollment scale of undergraduate colleges and universities, the number of students of all majors at school increases continuously in an explosive way. Furthermore, as the phenomenon of merger in the colleges and universities prevails and in order to meet the requirement of teaching level evaluation in undergraduate colleges and universities on the size of campus, the colleges and universities scruple their funds to purchase land. This leads to multi-campus district pattern and difficulty in teaching management increases exponentially compared with that previously. The working task of competent department of teaching becomes heavy and it is unlikely to frequently go deep into the frontline of teaching to know about the situation of all aspects in the process of teaching. 
In addition, it is difficult for them to take time off at ordinary times to supervise the lecture schedule of teachers, their lecture quality, their making up missed lessons and whether they come to work late and leave early. The information feedback function of teaching information staff makes it possible for management personnel to, within a short period of time, have an idea of the teaching condition in time and to resolve all kinds of problems existing in the process of teaching in time so as to improve the quality of teaching. Implementation of the system of teaching information staff provides evidence for the management department to work out relevant system and policy and scientific decision making to ensure normal teaching order and helps to boost improvement of teaching quality and management level of teaching.

\subsection{To Help to Enhance the Teaching Level of Teachers}

The teaching information staff make relatively fair and objective evaluation on the teaching attitude, teaching method, teaching means, teaching effect and teaching content of teachers and send the information feedback to the competent teaching department or the college. Then, the relevant department is able to handle the feedback appropriately. The teachers who get positive feedback will be given credit and for those who get negative feedback, the competent teaching department can arrange teaching supervision experts to attend a lecture by them and ascertain whether the negative feedback is true. If the teachers are confirmed to have any problem, the competent department should have an informal discussion with them to enable them to come to realize their problems and help them improve their teaching level. The system of teaching information staff helps each teacher to be aware of their own advantages in the process of teaching so as to make corrections in time and encourage teachers to continuously consummate and enhance the teaching quality. This makes for formation of a positive style of learning and improvement of the teaching effect.

\subsection{To Help to Form a Good Style of Learning}

Students are the ultimate beneficiary of teaching management and are the subject of school education. Thus, it is necessary to let students take active participation in teaching management of the school to strengthen close connection with the management department and teachers. As the subject of learning, students have a sober cognition in the style and condition of learning. Thus, if these problems are sent as feedback to the competent teaching department, the competent department is able to suit the remedy to the case and work out countermeasures in due course to provide rational management and correct guidance. It is necessary to strengthen students' consciousness of master in the school and enhance their ability to take active participation in the teaching management. This is of positive significance to cultivate talents imbued with independence and innovative spirit and to form a positive style of learning.

\subsection{To Supervise the Situation of Usage of Teaching Materials}

Students have, all the time, had largely different opinions on usage of teaching materials in undergraduate colleges and universities. From their view of point, either the teaching materials ordered do not suit with development of the major, or the teachers do not lecture in complete compliance with the teaching materials. As a result, the teaching materials merely serve as reference books. Thus, students are somewhat resistant to the teaching materials ordered by the colleges and universities. Reservation of teaching materials in undergraduate colleges and universities is almost done by course teachers and the teaching material management department finally approves after the department head and the teaching dean examine and agree. It seems that the procedure is relatively standard, but actually it becomes a mere formality. The course teachers fail to make a comparison of choice with the teaching materials of the same kind with discretion. Or they merely choose the teaching materials which their colleagues and they themselves are familiar with and which are recommended by the promoters of teaching materials they have used. They take a random attitude and, thus, the quality of teaching materials they have chosen fails to reach a standard. Students are the users of the teaching materials and student teaching information staff make a follow-up of quality of teaching materials and send information feedback. This provides guarantee and evidence for the undergraduate colleges and universities to make clear whether the teaching materials they have ordered for all courses are scientific and rational and for them to select appropriate teaching materials in the future.

\section{Mechanism of Management}

\subsection{Construction of Institutions}

An independent organization institution is an important safeguard for collection and feedback of teaching information. It is necessary to let management personnel to take part in construction and management of the team of student information staff and to work out relevant system. The system of teaching information staff in our university is organized and carried by the office of teaching affairs. The leading organization of the team of student information 
staff in our university is the teaching information station. Each college appoints one station head and each grade appoints one assistant station head who are both information staff recommended by the college. Each class recruits and appoints one information staff. And the teaching quality department of the office of teaching affairs takes responsibility for handling of ordinary affairs.

\subsection{Recruitment and Appointment and Qualifications}

The teaching information staff are recruited and appointed once each academic year and will be automatically appointed further after they pass the assessment. The recruitment will come to an end automatically after graduation of the teaching information staff. The office of teaching affairs is responsible for making an assessment of the working condition of student teaching information staff of the entire university. If the student information staff fail to send any relevant information feedback within a month and finish in an effective way related jobs assigned in time, or if they violate any school regulation or school discipline over tenure, they will be dismissed at any time. Accordingly, their letter of appointment will be taken back. The college ought to make up for student information staff in time if any information staff is dismissed or if any class drops out midway.

Qualifications for a student information staff include being excellent in both character and learning; being practical and realistic and being impartial and fair in sending information feedback; daring to come out with their own opinions; being diligent and conscientious in dealing with concrete issues; strong spirit of solidarity and cooperation; being good at connecting with teachers and students and sending feedback on behalf of students; strong observation and perceptivity capacity; being good at seizing information and discovering problems; strong information analysis, comprehensive capacity and perfect literal expression capacity; taking the initiative to learn advanced teaching concepts, focusing on the leading edge condition of teaching and being familiar with the current situation of the teaching reform.

\subsection{Obligations of Recruitment and Appointment}

The teaching information staff are mainly responsible for collecting such information as teaching management, classroom teaching, style of learning and teaching conditions in the process of teaching in undergraduate colleges and universities. They fill in "Teaching Information Feedback Form of Information Staff", which is collected and sorted out by the assistant station head and is then submitted to the station head of the college. After the latter sorts out the information collected, he hands it over each Monday to the teaching quality department of the office of teaching affairs. And the teaching quality department arranges specially-assigned persons to take responsibility for sorting out and assortment of the information and to send the information feedback in due course to relevant leaders and teachers of the management department. The latter will write out a solution and send it back to the teaching quality department who will then send the information feedback to the student information staff. It is the teaching information staff that supervise the rectification measures and effects. For emergency circumstances, they may directly make a call or post message through QQ as feedback. This forms a closed-loop management flow, as is shown in the following figure.

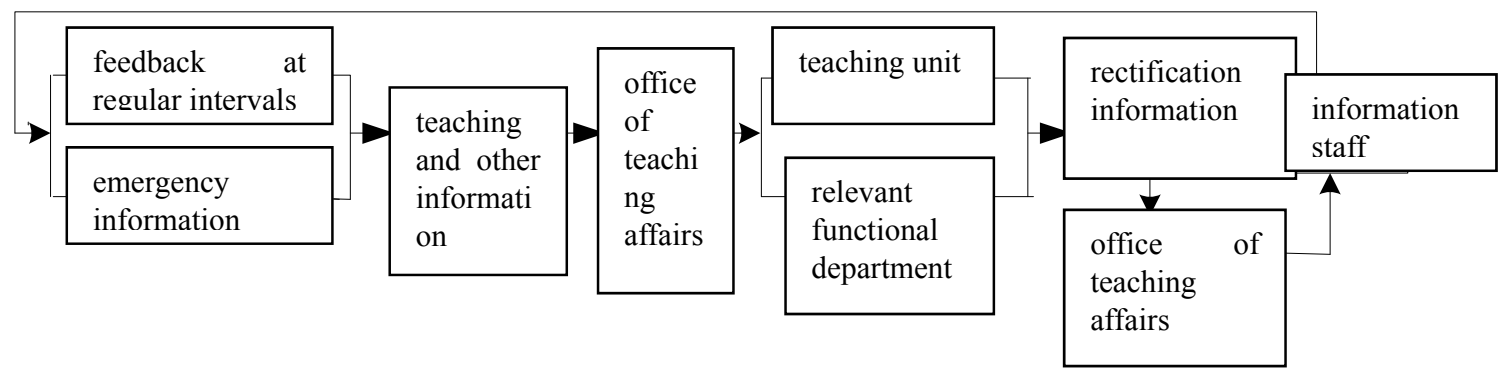

2.4 To Hold a Grand Recruitment and Appointment Ceremony to Stimulate the Sense of Work Responsibility and Sense of Reputation among Student Teaching Information Staff

Each year when the newcomers enter the school, the office of teaching affairs organize the job of recruiting new members for the team of student information staff. On the ceremony of recruitment and appointment, both former and new information staff make excited and enthusiastic speeches and leaders from the office of teaching affairs and teacher representatives express their wishes and put forward requirements. The most ceremonious part is that the school president who is in charge of teaching awards personally the letter of appointment. When the new members take over the letter of appointment, it actually means that they have assumed a responsibility. And this strengthens their sense of working responsibility. 


\subsection{To Establish Regular Symposium System to Ensure the Job Carried out in Good Order and Effectively}

It is necessary to hold, at regular intervals, a symposium for communication and opinion feedback of teaching information staff and to make records on attendance at each regular meeting, which is one of proofs for evaluation of excellence. It is also necessary to notify information staff about the working condition in the recent one month and to ask them to mutually communicate about their experiences and information and to discuss countermeasures and implementation plans for the month to follow.

\subsection{Incentive Mechanism}

An annual assessment is made based on the working condition of student teaching information staff and the feedback information of information staff is kept in the archives for check. Particular substance and moral encouragement will be given to the information staff who behave well, work enthusiastically, finish their work task as scheduled, provide high quality feedback information and have outstanding performance. They will be awarded certificate of merit and prize. This is to attempt to form a positive and upward atmosphere and an earnest and steadfast style of work in the team of teaching information staff by means of establishing and commending advanced characters.

\section{Problems Existing in the Process of Implementation}

\subsection{Doubts of Management Personnel, Teachers and Information Staff}

The management personnel are worried that the members in the team of information staff come from different backgrounds and lack an earnest attitude towards their work and that the problems they report might carry deep personal emotions. Therefore, this will cause the management personnel to deny the authenticity of the teaching information provided by the information staff. The teachers are worried that the information staff might not have a clear idea of the teaching method and teaching process or might hold a personal hostile attitude towards them. Therefore, the problems reported by the information staff are merely the subjective opinions of students themselves, which will bring about invisible pressure to teachers in the process of teaching and, sometimes, may even have a direct impact on teachers' personal benefits. What's more, the information staff are worried that the teachers may not treat with the problems they have reported in a proper way, which may affect their personal school performance. Therefore, the information staff neither dare to carry out the work in a deep-going way nor dare to disclose problems actually existing in the process of teaching.

\subsection{Impossibility to Form an Effective Closed-loop Supervision Mechanism}

As for the problems or suggestions in the process of teaching reported by the information staff, the fact is that, sometimes, the feedback opinions of all competent departments are unlikely to propose a resolution in time or, even if a resolution is proposed, it is unlikely to be put into practice rapidly. As a result, the problems still exist and this affects the quality of teaching. Furthermore, the resolution proposed fails to be instantly conveyed to the teaching information staff. This makes it impossible to form a closed-loop supervisory mechanism and, thus, also causes the information staff to lack enthusiasm in the work, affecting the effect of implementation of the wish system.

\subsection{Low Working Level of Information Staff}

As the team of teaching information staff adopts the mode of voluntary participation and a loose management mode, this gives rise to a gap between the quality of the information staff. Some information staff are unable to go deep into the massive number of students, so their capacity in recognizing problems, analyzing problems and expressing is seriously deficient. What's more, some others do not hold an earnest attitude towards the work, get through a matter carelessly and report feedback information with inferior quality. Ultimately, this will affect the overall working efficiency of the information staff.

\section{Concluding Remarks and Thoughts in the Process of the Construction the System for Teaching Information Staff}

It is necessary to set up campus network information feedback platform, make information collection with the help of the internet in an instant and rapid way and develop information feedback system of information staff. Both information feedback and disposal opinion can be finished through this network. It is able to greatly strengthen information feedback and disposal speed and enlarge information feedback channel.

\subsection{To Enhance Ideological Cognition of Teaching Management Personnel and Teachers}

The teaching management personnel are supposed to attach great importance to the information acquired through the channel of student teaching information staff and make careful analysis and discrimination of the information. Neither should they completely negate the authenticity of all other information due to inauthentic information of 
some students, nor they should make a decision without making a comprehensive analysis of the information. The teachers ought to regard the feedback opinions of students as a means to stimulate themselves and consummate their teaching mode instead of keeping a wary eye on the information staff. Also, it is necessary to change teachers' emotion of resistance to the work of information staff.

4.2 To Strengthen the Sense of Work Responsibility of Information Staff and to Set up an Information Staff Team with High Quality

With completion of all kinds of rules and regulations, ideological and capacity cultivation of information staff becomes especially important. Only the information staff with good quality are able to report feedback information in the process of teaching in a correct and fair way and reduce doubts of both the management personnel and teachers. This requires to strengthen cultivation on ideological quality, coordination capacity, discrimination capacity and participation capacity of the information staff, which is the basis to enable them to do a better job.

\subsection{To Consummate the Reward Mechanism of Information Staff}

It is necessary to carry out annual assessment to stimulate the enthusiasm of information staff in work. One cycle of assessment is required at the end of each academic year. The assessment is made on both the teaching information station and the information staff according to the quantity and quality of information provided by the information staff. An excellent working station and an excellent information staff are selected for which the certificate is awarded and some substance rewards are given.

The system of teaching information staff is an important element in the system of control over teaching quality in undergraduate colleges and universities and plays a role not to be neglected in strengthening the teaching quality management in undergraduate colleges and universities. It is still necessary to search for rules and innovation in the teaching activities continuously changing and to continue to enrich and consummate the system of teaching information staff.

\section{References}

Dan, Xinguang, \& Liu, Zhaojun. (2004). Strengthening Construction of the Team of Teaching Information Staff and Promoting Improvement of Teaching Quality. Journal of Jianghan Petroleum University of Staff and Workers, (5), 40 .

Kang, Jijun, Li, Changping, \& He, Yunfeng. (2006). Thoughts on Construction of the Team of Teaching Information Staff in Colleges and Universities. Journal of Shanxi Agricultural University, 5(5), 63-65.

Wang, Haiping, \& Ding, Jinguo. (2006). An Attempt to Construct the System of Student Teaching Information Staff. Beijing Education, (7-8), 90-91. 